\title{
THE INFLUENCE OF BLANCHING PROCESS ON DEHYDRATED PLUM FRUIT QUALITY
}

\author{
Sándor Rózsa ${ }^{1}$, Vasile Lazăr ${ }^{1}$, Orsolya Borsai ${ }^{1, *}$, Tincuța-Marta Gocan ${ }^{1}$, Ileana Andreica ${ }^{1}$, \\ Emese Egyed ${ }^{1}$, Melinda Rózsa ${ }^{1}$ \\ ${ }^{1}$ University of Agricultural Sciences and Veterinary Medicine, \\ Faculty of Horticulture, 400372, 3-5 Mănăştur Street, Cluj-Napoca, Romania
}

\section{Current Trends in}

Natural Sciences

\begin{abstract}
Dehydrated plums are distinguished by a pleasant taste, but at the same time they are also distinguished by a special nutritional value, which brings many benefits to human health. After apples, plums are the most cultivated fruits in Romania. Quality as a notion is a general and specific characteristic being represented by certain features that condition both the marketing and the use of the finished product. The physical condition of dehydrated plums is determined by the anatomical structure, structural firmness, water content and appearance. The composition of the soluble dry matter is influenced by the variety, the degree of maturation, at which the raw material has been processed and by the qualitative changes undergone by each component, during dehydration. In this paper, we followed the influence of blanching treatment on 4 varieties of plums, dehydrated in a stream of warm air, at a temperature of $70{ }^{\circ} \mathrm{C}$. The fruits taken into analysis were characterized by a water content of 75-84\%, soluble dry matter 9-24\%, total sugar 7-13\%, acidity 0.45-0.98\% and 2-17 mg ascorbic acid. After dehydration, the analyzed parameters were as follows: 16$24 \%$ water, total sugar $31-51 \%$, total acidity $1.1-2.3 \%$.
\end{abstract}

Keywords: acidity, blanching treatment, dehydrated plums, quality, sugar

\section{INTRODUCTION}

Plums are one of the most important stone fruits of the world considered as functional food due to their valuable nutrient profile. Plums are an excellent source of vitamins A and C, minerals such as calcium, magnesium, potassium, iron and dietary fibers as well as antioxidants (Mehta et al., 2014). Similar to other fruits, plums have a low content of fats and calories and are rich in carbohydrates (Doymaz, 2004). However, health benefits of this fruits are highly influenced by their consumption rate and way of consumption (Pocol et al., 2015). They can be used in a wide variety of ways as natural or processed, dried or dehydrated as a whole for snacks, chopped to add some sweetness to salads or cakes. Recently, the In Romania, following apples, plums are the second most commonly grown fruit trees over the country. The general harvest period for plums is from the end of August until the end of September depending on the variety. Therefore, the availability of fresh plum fruits on the market is relatively short and unsatisfactory for the continuously increasing consumers' demand for nutritious and natural foods. This remarkable increase makes the consumers to look for other ways of consumption of these sweet and tasty gems such as processed product or as ingredients to other products. Dehydrated foods undergo minimal changes in their nutritional value 


\begin{tabular}{lr}
\hline & $\begin{array}{c}\text { Current Trends in Natural Sciences } \\
\text { Vol. 10, Issue 20, pp. 179-185, 2021 } \\
\text { https://doi.org/10.47068/ctns.2021.v10i20.024 }\end{array}$ \\
\cline { 2 - 3 } $\begin{array}{l}\text { Current Trends in Natural Sciences (on-line) } \\
\text { ISSN: 2284-953X }\end{array}$ & Current Trends in Natural Sciences (CD-Rom) \\
ISSN-L: 2284-9521 & ISSN: 2284-9521 \\
ISSN-L: 2284-9521 \\
\hline
\end{tabular}

keeping most of their nutrient content, and they do not require additional sugar. In fact, the dehydration process concentrates the natural sugars of the fruits, reason why fruit leathers made from fresh fruits such as peaches, plums or other orchard fruits are delicious and healthy (Momchilova et al., 2016; Singh et al., 2019). Consumption of dried plums might decrease the risk of chronic diseases, exhibit anticancer, antimicrobial, antiallergenic, antimutagenic, antitrombothic and anti-inflammatory properties and relieve constipation (Forsido et al. 2013; Rubio-Perez et al. 2014; El-Beltagi et al., 2019). All these effects are associated with the biologically active components such as phenolic compounds, flavonoids, carotenoids, vitamins C, and dietary fiber that are naturally present in the fruit (Stacewicz et al., 2001; Kim et al., 2013). Physical properties of dehydrated plums are highly-dependent on the anatomic structure, firmness, water content and general aspects of the fruits. The composition of soluble dry matter is determined by the variety, ripening stage (when the fruits were processed), and changes in quality of every individual compound undergoing the dehydration process. Therefore, the aim of this research was to investigate the influence of the blanching method upon four different plum cultivars namely, 'Jojo', 'Stanley', 'Elena' and 'Tuleu gras', dehydrated due to hot air drying at $70{ }^{\circ} \mathrm{C}$ checking thus the preservation of the desirable quality attributes of the fruit. In this context, water content, soluble dry matter, total soluble sugars, malic acid and ascorbic acid were quantified as the most important parameters of fruit quality. The result obtained could serve as valuable information for any industry of drying fruits to optimize the processing conditions and reduce the costs of production.

\section{MATERIALS AND METHODS}

Fruit collection and samples

The plums of the four cultivars ('Jojo', 'Stanley', 'Elena' and 'Tuleu gras') had been harvested at their commercial maturity from the Horticultural Research Station of Cluj-Napoca and Experimental Orchard of the University of Agricultural Sciences and Veterinary Medicine of ClujNapoca located in Cluj-Napoca, Romania. All varieties chosen for this research have medium or big sized, round or slightly oval-shaped fruits with dark purple skin color (Figure 1).

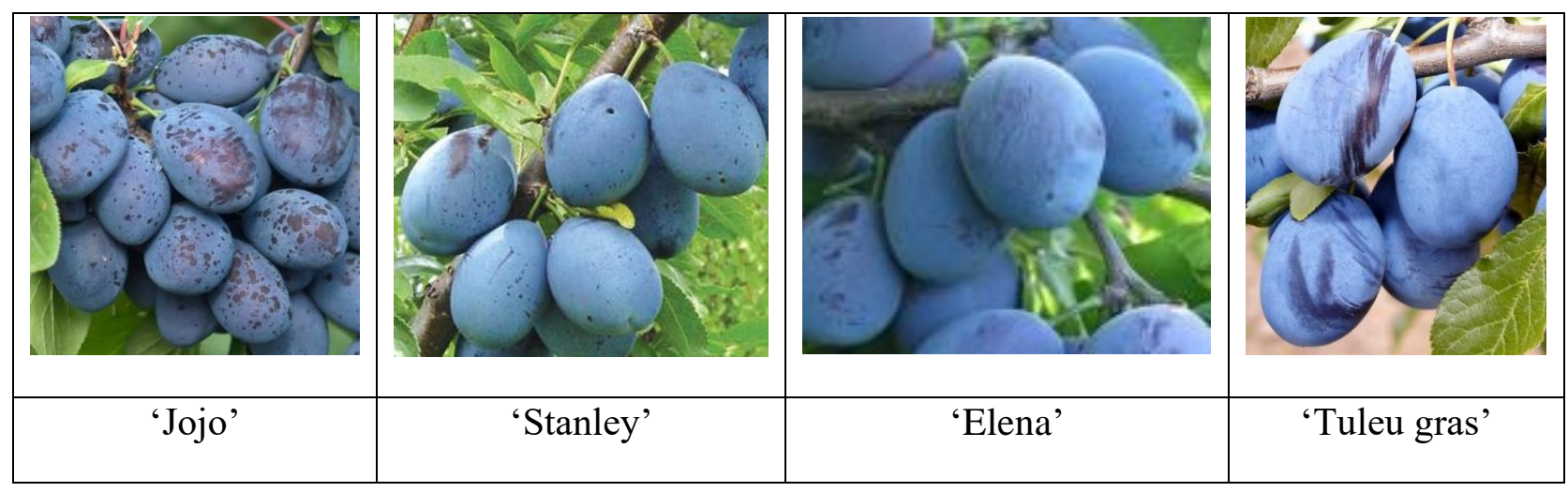

Figure 1. Plum cultivars and their characteristics used for this research

The initial weight of the fruits was measured immediately after harvest and then transported into the laboratory and stored refrigerated at $5{ }^{\circ} \mathrm{C}$ before the dehydration process and chemical analyses. Before the dehydration process, plum samples were selected by size then washed carefully and dried with absorbent paper. The stones were removed and the plums were carefully cut in slices. 


\section{Current Trends in Natural Sciences}

Vol. 10, Issue 20, pp. 179-185, 2021

https://doi.org/10.47068/ctns.2021.v10i20.024

Current Trends in Natural Sciences (on-line)

\section{Water content and soluble dry matter determination}

The water content and soluble dry matter content of the plum samples were determined after the hot air-drying process by Abbe refractometer (accuracy \pm 0.01 ) (AOAC 1975).

Hot-air drying

The uniform sized fruit were placed on a tray and dehydrated using a hot-air laboratory convective dryer, being the most common method practiced industrially. The plums were cut into equal slices, then blanched in hot water at $85^{\circ} \mathrm{C}$ for 1 minute, cooled and dried at $70{ }^{\circ} \mathrm{C}$ for 24 hours (Figure 2).

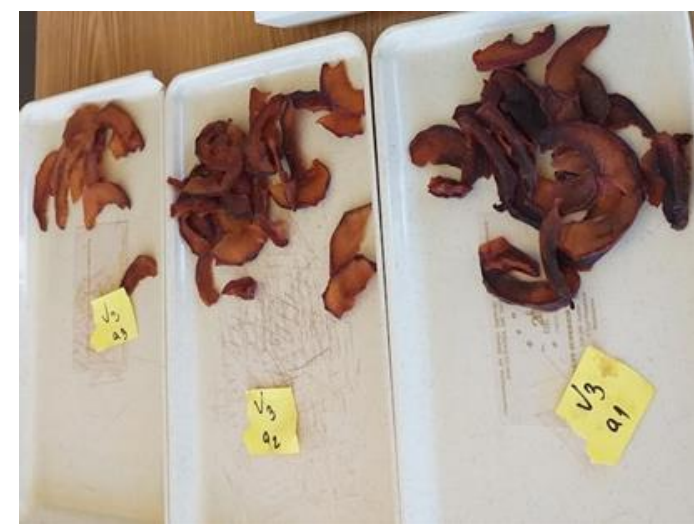

Figure 2. Dehydrated sliced plums.

During the drying process, moisture losses of the plum fruits were recorded at 60 minutes intervals by a digital balance. The drying process was ended when the dry matter content of the plum samples reached approx. $75 \%$.

Determination of acidity

The determination of acidity was performed by titration with sodium hydroxide in the presence of phenolphthalein (Rózsa et al. 2020).

\section{RESULTS AND DISCUSSIONS}

In order to establish the quality of the raw material subjected to dehydration, the unilateral influence of the variety on the soluble dry matter content was determined, the results obtained being presented in table 1.

Unilateral influence of the variety on the soluble dry matter content of fresh samples

\begin{tabular}{|c|c|c|c|c|}
\hline \multirow[b]{2}{*}{ Variety } & \multicolumn{2}{|c|}{ Soluble dry matter } & \multirow{2}{*}{$\begin{array}{c}\text { Difference } \pm \\
\%\end{array}$} & \multirow{2}{*}{$\begin{array}{l}\text { Significance of } \\
\text { difference }\end{array}$} \\
\hline & $\begin{array}{c}\text { Absolute value } \\
\%\end{array}$ & $\begin{array}{l}\text { Relative } \\
\text { value \% }\end{array}$ & & \\
\hline 'Jojo' & 75.57 & 93.9 & -4.94 & 000 \\
\hline 'Stanley' & 80.47 & 99.9 & -0.04 & - \\
\hline 'Elena' & 83.87 & 104.2 & 3.36 & $* * *$ \\
\hline 'Tuleu gras' & 82.13 & 102.0 & 1.63 & $* * *$ \\
\hline Average & 80.51 & 100.0 & 0.00 & Mt. \\
\hline DL (p 5\%) & & & 0.41 & \\
\hline DL (p 1\%) & & & 0.62 & \\
\hline $\mathrm{DL}(\mathrm{p} 0.1 \%)$ & & & 1.00 & \\
\hline
\end{tabular}




\section{Current Trends in Natural Sciences}

Vol. 10, Issue 20, pp. 179-185, 2021

https://doi.org/10.47068/ctns.2021.v10i20.024

Current Trends in Natural Sciences (on-line)

ISSN: 2284-953X

Current Trends in Natural Sciences (CD-Rom)

ISSN: 2284-9521

ISSN-L: 2284-9521

ISSN-L: 2284-9521

Thus, following the unilateral influence of the variety on the soluble dry matter content of the samples before dehydration, the varieties 'Elena' and 'Tuleu gras' showed very distinctly significant differences from the average experience, which was considered as a control. The 'Jojo' variety registered very distinctly significant negative differences compared to the experience average, and for the 'Stanley' variety the results obtained were not statistically assured. The data obtained by us for the soluble dry matter content of the samples before dehydration are comparable to those presented in the scientific literature by Doymaz, 2004 and Pocol et al., 2015.

Data on the content of fresh samples in total sugar, before dehydration, are presented in Table 2.

Table 2

\begin{tabular}{|c|c|c|c|c|}
\hline \multirow[b]{2}{*}{ Variety } & \multicolumn{2}{|c|}{ Total sugar content } & \multirow{2}{*}{$\begin{array}{c}\text { Difference } \pm \\
\%\end{array}$} & \multirow{2}{*}{$\begin{array}{l}\text { Significance of } \\
\text { difference }\end{array}$} \\
\hline & $\begin{array}{c}\text { Absolute value } \\
\%\end{array}$ & $\begin{array}{l}\text { Relative } \\
\text { value \% }\end{array}$ & & \\
\hline 'Jojo' & 11.67 & 62.2 & -7.10 & 000 \\
\hline 'Stanley' & 20.40 & 108.7 & 1.63 & $* * *$ \\
\hline 'Elena' & 23.73 & 126.5 & 4.97 & $* * *$ \\
\hline 'Tuleu gras' & 19.27 & 120.7 & 0.50 & $*$ \\
\hline Average & 18.77 & 100,0 & 0.00 & Mt. \\
\hline \multicolumn{3}{|l|}{ DL (p 5\%) } & \multicolumn{2}{|l|}{0.49} \\
\hline \multicolumn{3}{|l|}{$\mathrm{DL}(\mathrm{p} 1 \%)$} & \multicolumn{2}{|l|}{0.74} \\
\hline \multicolumn{3}{|l|}{$\mathrm{DL}(\mathrm{p} 0.1 \%)$} & \multicolumn{2}{|l|}{1.19} \\
\hline
\end{tabular}

Following the unilateral influence of the variety on the total sugar content, in the case of fresh samples, before dehydration, it can be seen that the varieties 'Stanley' and 'Elena' showed very distinctly significant positive differences from the experience average, which was considered as control. In this case, the 'Tuleu gras' variety registered significantly positive differences compared to the experience average. The 'Jojo' variety compared to the average experience and compared to the other varieties studied, in the case of the total sugar content before dehydration, shows very distinctly significant negative differences. Also, in this case, the data recorded for the sugar content of fresh samples are comparable to those obtained by Mehta et al., 2014, Momchilova et al., 2016, Singh et al., 2019.

The data of the samples acidity before dehydration are presented in Table 3 .

Table 3

Unilateral influence of the variety on the acidity content of fresh samples

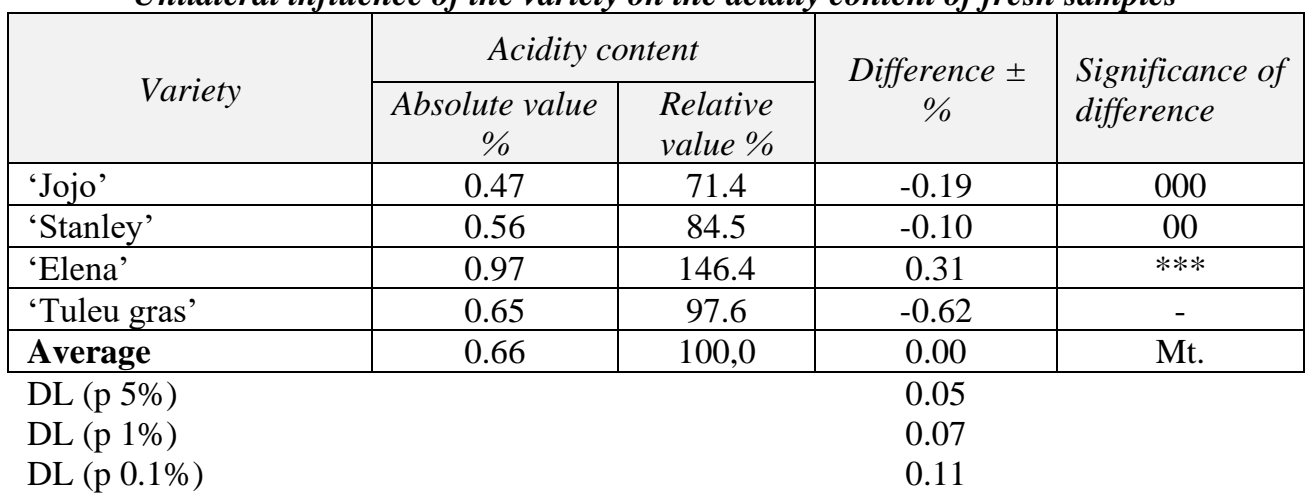




\section{Current Trends in Natural Sciences}

Vol. 10, Issue 20, pp. 179-185, 2021

https://doi.org/10.47068/ctns.2021.v10i20.024

Current Trends in Natural Sciences (on-line)

ISSN: 2284-953X

Current Trends in Natural Sciences (CD-Rom)

ISSN: 2284-9521

ISSN-L: 2284-9521

ISSN-L: 2284-9521

Looking at the unilateral influence of the variety on the acidity content of fresh plum samples, before dehydration, it can be seen that the 'Elena' variety registered very distinctly positive differences compared to the average of the experience considered as a control. The 'Jojo' and 'Stanley' varieties recorded negative differences compared to the experience average in terms of the acid content of fresh plums. The 'Tuleu gras' variety in terms of acidity content did not show statistically assured results. The data obtained on the acidity content of fresh plum samples are comparable to those presented in the literature by Forsido et al. 2013, Rubio-Perez et al. 2014 and El-Beltagi et al., 2019.

Table 4 shows the unilateral influence of the variety on the water content after dehydration.

Unilateral influence of the variety on the water content after dehydration

Table 4

\begin{tabular}{|c|c|c|c|c|}
\hline \multirow[b]{2}{*}{ Variety } & \multicolumn{2}{|c|}{ Water content } & \multirow{2}{*}{$\begin{array}{c}\text { Difference } \pm \\
\%\end{array}$} & \multirow{2}{*}{$\begin{array}{l}\text { Significance of } \\
\text { difference }\end{array}$} \\
\hline & $\begin{array}{c}\text { Absolute value } \\
\%\end{array}$ & $\begin{array}{l}\text { Relative } \\
\text { value \% }\end{array}$ & & \\
\hline 'Jojo' & 22.50 & 107.1 & 1.50 & $* *$ \\
\hline 'Stanley' & 10.50 & 97.6 & -0.50 & - \\
\hline 'Elena' & 23.60 & 114.4 & 2.60 & $* * *$ \\
\hline 'Tuleu gras' & 17.42 & 82.9 & -3.58 & 000 \\
\hline Average & 21.01 & 100,0 & 0.00 & Mt. \\
\hline \multicolumn{3}{|l|}{ DL (p 5\%) } & \multicolumn{2}{|l|}{0.65} \\
\hline $\mathrm{DL}(\mathrm{p} 1 \%)$ & & & \multicolumn{2}{|l|}{0.98} \\
\hline $\mathrm{DL}(\mathrm{p} 0.1 \%)$ & & & \multicolumn{2}{|l|}{1.57} \\
\hline
\end{tabular}

Following the unilateral influence of the variety on the water content after dehydration, it can be seen that the 'Elena' variety has the highest water content of $23.60 \%$, registering a distinctly significant positive difference from the average experience, which was considered as control. Then followed the 'Jojo' variety, with $22.50 \%$ water, registering a distinctly significant positive difference compared to the average experience. For the 'Tuleu gras' variety, the results obtained showed a very significant negative difference compared to the experience average, and for the 'Stanley' variety the recorded results were not statistically assured. The data obtained by us are similar to those reported by Stacewicz et al., 2001 and Kim et al., 2013.

Table 5 shows the unilateral influence of the variety on the total sugar content after dehydration.

Unilateral influence of the variety on the total sugar content after dehydration

Table 5

\begin{tabular}{|c|c|c|c|c|}
\hline \multirow[b]{2}{*}{ Variety } & \multicolumn{2}{|c|}{ Total sugar content } & \multirow{2}{*}{$\begin{array}{c}\text { Difference } \pm \\
\%\end{array}$} & \multirow{2}{*}{$\begin{array}{l}\text { Significance of } \\
\text { difference }\end{array}$} \\
\hline & $\begin{array}{c}\text { Absolute value } \\
\%\end{array}$ & $\begin{array}{l}\text { Relative } \\
\text { value \% }\end{array}$ & & \\
\hline 'Jojo' & 31.67 & 80.9 & -7.47 & 000 \\
\hline 'Snley' & 38.40 & 98.1 & -0.73 & 0 \\
\hline 'Elena' & 51.07 & 130.5 & 11.93 & $* * *$ \\
\hline 'Tuleu gras' & 35.40 & 90.5 & -3.73 & 000 \\
\hline Average & 39.13 & 100,0 & 0,00 & Mt. \\
\hline \multicolumn{3}{|l|}{ DL (p 5\%) } & \multicolumn{2}{|l|}{0.56} \\
\hline DL (p 1\%) & & & \multicolumn{2}{|l|}{0.85} \\
\hline $\mathrm{DL}(\mathrm{p} 0.1 \%)$ & & & \multicolumn{2}{|l|}{1.36} \\
\hline
\end{tabular}




\section{Current Trends in Natural Sciences}

Vol. 10, Issue 20, pp. 179-185, 2021

https://doi.org/10.47068/ctns.2021.v10i20.024

Current Trends in Natural Sciences (on-line)

ISSN: 2284-953X

Current Trends in Natural Sciences (CD-Rom)

ISSN: 2284-9521

ISSN-L: 2284-9521

ISSN-L: 2284-9521

Regarding the sugar content of dehydrated plums, the 'Elena' variety has the highest amount of sugar $51.07 \%$, registering a very distinctly significant positive difference compared to the experience average. In the 'Stanley' variety, the total amount of sugars registered a significantly negative difference. Regarding the total sugar content of the 'Jojo' and 'Tuleu gras' varieties, they registered very significant negative differences compared to the average experience. The data obtained by us are comparable to those found in the literature by Momchilova et al., 2016 and Singh et al., 2019.

Table 6 presents the data obtained on the unilateral influence of the variety on the acidity content of dehydrated plums.

Unilateral influence of the variety on the acidity content after dehydration

Table 6

\begin{tabular}{|c|c|c|c|c|}
\hline \multirow[b]{2}{*}{ Variety } & \multicolumn{2}{|c|}{ Acidity content } & \multirow{2}{*}{$\begin{array}{c}\text { Difference } \pm \\
\%\end{array}$} & \multirow{2}{*}{$\begin{array}{l}\text { Significance of } \\
\text { difference }\end{array}$} \\
\hline & $\begin{array}{c}\text { Absolute value } \\
\%\end{array}$ & $\begin{array}{l}\text { Relative } \\
\text { value \% }\end{array}$ & & \\
\hline 'Jojo' & 1.83 & 101.9 & 0.03 & - \\
\hline 'Stanley' & 2.17 & 120.4 & 0.37 & $* *$ \\
\hline 'Elena' & 1.30 & 72.2 & -0.50 & 00 \\
\hline 'Tuleu gras' & 1.90 & 105.6 & 0.10 & - \\
\hline Media & 1.80 & 100,0 & 0,00 & Mt. \\
\hline \multicolumn{3}{|l|}{ DL (p 5\%) } & \multicolumn{2}{|l|}{0.23} \\
\hline \multicolumn{3}{|l|}{$\operatorname{DL}(\mathrm{p} 1 \%)$} & \multicolumn{2}{|l|}{0.35} \\
\hline \multicolumn{3}{|l|}{$\mathrm{DL}(\mathrm{p} 0.1 \%)$} & \multicolumn{2}{|l|}{0.56} \\
\hline
\end{tabular}

Following the data presented in table 6, regarding the unilateral influence of the variety on the acidity content of dehydrated plums, it can be seen that the 'Stanley' variety has the highest acidity value after dehydration $2.17 \%$, registering a distinctly positive difference from the experience average, considered as a control. The acidity values after dehydration for the 'Jojo' and 'Tuleu gras' varieties were not statistically assured, and the 'Elena' variety registered distinctly significant negative differences compared to the average experience. Thus, in this case, the data obtained are comparable to those found in the scientific literature reported by Forsido et al. 2013, Rubio-Perez et al. 2014 and El-Beltagi et al., 2019.

\section{CONCLUSIONS}

Each phase of dehydration in the studied plum varieties is characterized by a certain chemical composition. As the fruits subjected to dehydration approach the optimum level of humidity, the sugar-acidity ratio changes in favor of sugar, due to the bleaching of the raw material subjected to dehydration and the inhibition of their enzymatic activity.

Depending on consumer preferences and the results obtained, the following recommendations can be made:

$>$ for consumers who prefer softer dehydrated fruits, we recommend the varieties 'Elena' and 'Jojo';

$>$ for consumers who prefer sweet dehydrated fruits, we recommend the 'Elena' variety;

$>$ for consumers who prefer more acidic or sour dehydrated fruits, we recommend the 'Stanley' variety. 


\section{Current Trends in Natural Sciences}

Vol. 10, Issue 20, pp. 179-185, 2021

https://doi.org/10.47068/ctns.2021.v10i20.024

Current Trends in Natural Sciences (on-line)

\section{REFERENCES}

Doymaz, İ. (2004). Effect of dipping treatment on air drying of plums. Journal of food engineering, 64(4), 465-470.

El-Beltagi, H. S., El-Ansary, A. E., Mostafa, M. A., Kamel, T. A., Safwat, G. (2019). Evaluation of the phytochemical, antioxidant, antibacterial and anticancer activity of Prunus domestica fruit. Notulae Botanicae Horti Agrobotanici Cluj-Napoca, 47(2), 395-404.

Forsido, S. F., Rupasinghe, H. V., \& Astatkie, T. (2013). Antioxidant capacity, total phenolics and nutritional content in selected Ethiopian staple food ingredients. International journal of food sciences and nutrition, 64(8), 915-920.

Kim, M.-S., Kang, J.-H., Chung, K.-S., Won, M., \& Song, K. B. (2013). Effects of Dehydrating Agents on the Physicochemical Properties of Dried Plum (Prunus salicina L.) Slices. Journal of Applied Biological Chemistry, 56(1), 19-22. https://doi.org/10.3839/jabc.2013.004

Mehta, S., Soni, N., Satpathy, G., \& Gupta, R. K. (2014). Evaluation of nutritional, phytochemical, antioxidant and antibacterial activity of dried plum (Prunus domestica). Journal of Pharmacognosy and Phytochemistry, 3(2).

Momchilova, M., Zsivanovits, G., Milkova-Tomova, I., Buhalova, D., \& Dojkova, P. (2016). Sensory and texture characterisation of plum (Prunus domestica) fruit leather. Bulgarian Chemical Communications, 48, 428-434.

Pocol, C. B., Stan, L., Moldovan-Teselios, C. (2015). Sensory Analysis of Dehydrated Plums and Pears. Bulletin of the University of Agricultural Sciences \& Veterinary Medicine Cluj-Napoca. Horticulture, 72(2).

Rózsa, S., Lazăr, V., Gocan, T.M. (2020). Tehnologia produselor horticole 2 - îndrumător de lucrări practice, Ed. AcademicPres, Cluj-Napoca.

Rubio-Perez, J. M., Vidal-Guevara, M. L., Zafrilla, P., \& Morillas-Ruiz, J. M. (2014). A new antioxidant beverage produced with green tea and apple. International journal of food sciences and nutrition, 65(5), 552-557.

Singh, A., Sonkar, C., \& Shingh, S. (2019). Studies on development of process and product of plum fruit leather. Studies, 4(5).

Stacewicz-Sapuntzakis M, Bowen PE, Hussain EA, Damayanti-Wood BI, and Farnsworth NR (2001) Chemical composition and potential health effects of prunes: a functional food? Crit Rev Food Sci Nutr 41, 251-86. https://doi.org/10.1080/20014091091814

AOAC. Association of Official Agricultural Chemists, \& Horwitz, W. (1975). Official methods of analysis (Vol. 222). Washington, DC: Association of Official Analytical Chemists. 